Медіафорум : аналітика, прогнози, інформаційний менеджмент : зб. наук. праць. - Чернівці :

Чернівецький нац. ун-т, 2021. -

Том 9. - С. 186-193
Mediarorum: Analytics, Forecasts, Information Management: Collection of Research Articles. - Chernivtsi: Chernivtsi National University, 2021. Vol. 9. - pp. 186-193

https://doi.org/10.31861/mediaforum.2021.9.186-193

УДК: 325.25:324](477-192.2)

(с) Ілона Лаврук

\title{
THE CASE OF ELECTORAL ABSENTEEISM IN UKRAINE BORDERLAND, A CHALLENGE TO ELECTORAL MODEL IN EASTERN EUROPEAN DEMOCRATIC REGIME
}

Analyzing the electoral absenteeism turnout between 1990 and 2009, one can observe a strong decreasing tendency. Given the various factors that generate absenteeism mentioned in the literature, in this paper we aim to analyze the possible causes of absenteeism experienced in recent years in in Ukraine Borderland.

Keywords: electoral absenteeism, disappointment to the political system, distrust in the political system.

\section{Випадки виборчого абсентеїзму на українськомуу прикордонні, виклик виборчій моделі у східноєвропейському демократичному режимі}

Аналізуючи явку на виборах у 1990-2009 рр., можна помітити сильну тенденцію до ї̈ зниження. Враховуючи різні чинники, які породжують небажання голосувати згадані в літературі, у иій роботі ми прагнемо проаналізувати можливі причини виборчої недовіри і відповідно неголосування, які спостерігалися протягом останніх років на украӥнському прикордонні.

Ключові слова: виборчий абсентеїзм, розчарування в політичній системі, недовіра до політичної системи.

Analyzing electoral phenomenon, reinvented and retrieved after the events of 1989, with the restoration of democracy in Eastern Europe, we see a downward trend in the voters' interest, a trend evidenced by the increasingly low turnout. This trend is also found in the presidential elections. In 2009, when the first presidential elections were held separately from par-

${ }^{1}$ Здобувачка кафедри міжнародних відносин Прикарпатського національного університеу імені Василя Стефаника, E-mail: lavruk.taras@ukr.net 
liamentary elections, the proportion of decreasing the turnout was lower than in the parliamentary elections. In the case of the presidential election the stake is clearer - it is about voting a single candidate among several candidates that voters know and for whom they have opinions and feelings clearly outlined. In the presidential elections the attention of the citizens is stronger captured through the media - the „war" between the candidates is spectacular and has a strong emotional impact. The larger turnout in the case of the presidential election in comparison to the parliamentary elections is not related to reasoning about possible future benefits for society and individual, but is an intense manifestation of the feelings that voters have for one or another of the candidates.

With regard to referendums, the turnout was influenced by the other type of elections the referendums were sometimes associated with. Thus, in 2009, the fact that the referendum on unicameral parliament was associated with presidential elections generated a greater turnout. On the other hand, the association of the referendum on the uninominal vote system with the European Parliament elections in 2007 did not lead to an increase in voting. However, if in 1990 the turnout was a record unrivalled, the turnout for this type of election also decreased in time.

What really causes this phenomenon? What happened to our young democracy, only 21 years old? Is the civic consciousness decreasing? Lower interest in voting in the specific case of Eastern Europe can be explained in this way? In the literature dedicated to this subject it is shown that there is a worldwide trend of increasing absenteeism. Explanations given by some researchers refer to a crisis of democracy, drawing a warning about the implications such a crisis can have - the less the people are interested in politics and in the democratic process itself, the weaker is the internalisation of the democratic values at the level of the individual conscience, the worse the democracy will work and the government will cease to be democratic, it will not consider the integration of different social interests in conditions of political pluralism, but will turn into a simple management of the nation's destiny in a direction that has nothing to do with democracy. Analyses have been made about the factors that determine electoral absenteeism (Lane, J. E., Ersson, S., 2002).

Regarding the Western democracies, some researchers have identified individual characteristics of voters that can generate this type of behaviour (age, education, income, marital status, interest in politics), considering that the influences of these characteristics remain constant, they don't vary 
with the external environment (Partheymüller, J., 2011).

Another view on the phenomenon of electoral absenteeism considers that political contexts may lead voters to refuse to vote (Perea, E. A., 2002). These include factors that can generate an increase of the turnout, such as compulsory voting. - A third approach takes into account the interaction between the two categories of factors mentioned before, the individual and the systemic (Šiber, I., 2004). Other researchers believe that social interactions, specifically interpersonal discussions on political issues and expressed intentions of the speakers on the elections influence voting behaviour of individuals, an Interpersonal demobilization takes place (Troumpounis, O., 2010). Absenteeism is explained by the fact that people do not live in a social environment with mobilizing features; there aren't certain conditions that encourage electoral participation. And political competition creates a conflict, which has a negative effect in this regard. An analysis closer to Eastern Europe from the geographic, economic and historical point of view is carried out by a researcher in Croatia6. He 188 shows that in this country the presence or the absence of the citizens from

- voting is mainly influenced by two factors: their opinion about the usefulness of the individual electoral act and a sense of political responsibility. According to the author, who advocates voting, the electoral participation in the democratic process is itself a source of satisfaction, in addition to the alleged result of the elections. Citizen participation can give them a sense of belonging and of fulfilled duty and represents an educational act, in this way the individual is taught to take responsibility for his civic actions. Electoral behaviour in the former communist countries is of course different from the start from that from the countries that have functioned continuously on the basis of democratic principles. New democracies themselves, namely the political systems of these countries, are also different from those in Western Europe and North America.

The purpose of this initiative is to launch hypotheses about possible causes of increasing absenteeism in our country.

Undoubtedly, individual characteristics influence its behaviour, including the electoral behaviour. Scholars have shown that the more educated, more informed citizens are, the better position they have on the social scale (not always, we say, welfare must be accompanied by education) they participate more often to the elections. They are less concerned about personal immediate material matters, and their civic consciousness is in their case stronger. Assuming that the level of education, hardly quantifiable, has de- 
clined in recent years, and the financial situation of the Eastern Europe population has suffered a decline, these could be possible explanations for the lower turnout. However, we believe, the proportion of absenteeism is too high and the dynamics of turnout decline too fast to explain this phenomenon only on these factors.

There are other factors, such as the election date (if the elections are scheduled on holidays, when a many people go on trips) or the fact that some polling stations are moved, creating confusion among voters and so on, but, again, in our opinion, these factors cannot be held responsible for the sharp decline in the electoral turnout (Barometrul, 2007).

An important factor influencing the percentage of electoral participation proved to be the zone where the citizens live, in a rural or an urban zone As you can see, there is a tendency in recent years as rural turnout to be higher than urban turnout and this can be explained by the existence of another type of human relations in rural communities: the individual can hardly shirk from a civic duty, he is well known and judged by the community. This is about the membership to small groups that operate by different rules than larger ones. It is also possible that rural communities to have a local leader that manage successfully the turnout of people. This is not a bad thing since the leader or anybody else intervenes in the way people vote. The intervention may take the form of electoral bribery or it can be even a pressure from influential leaders.

One explanation could be given on the basis of the rural citizens' expectations in relation to the government that seem to be lower in comparison to the urban citizens, according to the Public Opinion Barometer from October 2007. An analysis over the evolution of various indicators relevant for Eastern European society in the last ten years has been made, including the citizens' satisfaction in relation to the activity of the government taking into account the residential areas people live in. It is noted that there is an almost constant offset between the satisfaction of the rural citizens and of the urban citizens in this matter. However, the allure of the two curves is equal, the curve corresponding to the satisfaction of the urban citizens being placed almost completely under the degree of dissatisfaction - 40. Electoral studies conducted in Eastern Europe in recent years have shown that the emotional factor, namely sympathy, and trust in politicians are mobilizing elements for voting. It is well known that in surveys made in recent years political parties, politicians, government and parliament have obtained the lowest scores at the questions regarding the trust 
of the population. Moreover, the people's confidence has fallen steadily. Even assuming that the citizens would try to vote retrospective, rationally, taking into account the past performance in government, and we refer to both economic performance and the extent to which the politicians have complied with the promises they made in the electoral campaigns, the low confidence in the representatives of the political class, regardless of political colour, demobilized them when it comes to the electoral act. If the electoral messages of the politicians would be sufficiently strong, if the hopes of the individuals in relation to the government would be somehow increasing, then we believe that the turnout in Eastern Europe increases too. Unfortunately, people often vote «the lesser evil» candidate.

What causes low trust in politicians? Expected economic measures for the economic recovery during the economic crisis, underfunding education and public health systems, high corruption, all these elements that seem to grow do not provide a favourable climate for a young democracy, but on the contrary.

190 Suspicions about the fairness of the elections have even appeared repeatedly. Citizens are thus in a position to ask: «Whom do I vote?» And finally, many of them refuse to participate to the elections. Referring to potential absentee citizens and eliminating those who do not vote because of lack of civics or because they are in a specific situation that does not objectively allow them to vote, they can be in two situations:

no candidate seems to be able to give them what they want, none of them have convinced them, and they are still undecided. Therefore, they are indifferent or almost indifferent who will be the winner. These are the people that the political marketing is trying to determine to make a choice.

They are disappointed and convinced that they cannot influence in any way, either by vote, or otherwise, the current situation. A vote given with conviction can generate, after a strong disappointment, a rejection equal to the initial confidence, so the citizen promises himself that he will never vote again.

These are the determined absentee citizens. There are both a rational side of the decision not to vote, in the interior economy of the individual the effort of going to vote is no longer justified, and an emotional side - he feels cheated and humiliated.

The enthusiasms, the passion of the political discussions and the passionate political partisanship from the beginning of the '90s have disappeared. They are no longer held by hope. In many cases even the vote is 
only a gesture by which the citizen tries to remove from the competition the competitor whom he dislikes the most. And electoral absenteeism is, in many cases, a silent protest against the current state in politics, an act of signalling that politicians should take into account. If in a democracy where the problems are few the voters absent from voting because they feel that things are going well and without their intervention - thus having a free ride behaviour - in our case absenteeism may mean that citizens consider that everything in the society is going to be as bad as they were no matter how or whom they would vote. They choose to go abroad to work, to learn, to be treated when they are ill, each according to its age, its labour force, to the level of training or to their financial possibilities. Even some politicians give a signal in this sense - they send their children to schools abroad and they chose to go to be treated at clinics in Western Europe when they have problems. And then what is going to happen? How do we prepare the future for our children? In what kind of country shall they live? We ask these rhetoric questions for we believe, like Barbu Stefanescu Delavrancea, the Eastern Europen writer, that this country is not ours, but it belongs to our descendants to the descendants of our descendants. One way to check in a certain extent if the absence from the voting process is more a protest against the current political system or it's simply a personal decision without this substrate, caused by other factors, would be a campaign of intense explaining through media of the role of the white vote or "the civic absenteeism" as it is also called (Declinul...) This variant, present in Eastern European electoral law 11, but insufficiently publicized, may prove the Eastern Europeans' desire to protest, but certainly does not solve the problem generating absenteeism. There were opinions that on the voting-paper should be an option called "nobody", thus avoiding the confusion between the white votes and the null votes and eliminating the possibility of mystifying the elections by stamping the paper with a white vote after the voting is over (Legea...). Question remains whether voters are willing to make an effort and come to the voting in order to use this kind of protest. Considering the political scene as a market where there is demand and supply of public goods and services, the lack of a viable supply lead to imbalance, demand remains unsatisfied, and the democracy collapses. Which would be, briefly, the failures of governance? Privatization often led to failure and many former factories lie abandoned on the outskirts of the cities while people remained unemployed. Our highways are extremely expensive and are made very slowly. 
Are built mainly supermarkets and shopping malls, on the lands where once were factories or in buildings left unfinished at the time of socialism, all of this with the purpose of making us loyal consumers. Agriculture is in the mess, and the lands are bought by foreigners who came here to make the agriculture that we are too poor or too incompetent to do. Citizens pay health insurance and on the other hand the medical assistance is increasingly less and more expensive, and the retirees are considered assisted. The education system in which they send their children is under-funded and apparently ineffective. Salaries are frozen, but utilities are expensive and give politicians in power are always blaming the previous political leadership. This creates an imbalance that generates, among other serious things, a falling turnout.

With presidential elections as an example that generates a higher interest among the voters, we believe it would help changing the way the elections are designed, in the sense that voters should really get to know their elected representatives, and if the voting system is made on uninomi192 nal principles, and we think that this is a positive fact, this must mate-

- rialize in the method of determining the election winners. We advocate for compulsory political education at all levels in order the citizens to be more informed (a citizen well informed votes knowingly and it is harder to be manipulated) and for increasing civic awareness and responsibility through education. Political and civic education can lead to awakening the individual consciousness of citizens, who must try to make as much as they can for the community, to country living, if only by working, getting informed and voting.

On the other hand, the political class, those who wish to be elected, must offer a serious, well-founded political and economic programme, coherent ways for economic recovery, but also measures to decrease corruption and thieves. They should be aware that they are not separate entities from the citizens, but they are in a relation of principal - agent with them, that their role is to work for the good of the country and that they must stay constantly in touch with the voters to find out their wishes and complaints. This is also true for the political parties as a whole. And last but not least, we advocate for the freely consented presence at to vote for absenteeism is a great danger, it makes impossible the functioning of democracy. The lower is the percentage of the turnout; the lees the election results reflect the wishes of the citizens. And if those who vote are poorly informed, and less educated, the result will be even less satisfactory. 


\section{References:}

1. Lane, J. E., Ersson, S., (2002), Macro and micro understanding in Political Science: What explains electoral participation?, European Journal of Political Research, Vol. 18, pp. 457-465, 1990, apud Eva Anduiza Perea, „Individual characteristics, institutional incentives and electoral abstention in Western Europe”, European Journal of Political Research, Vol. 41, Issue 5.

2. Partheymüller, J., (2011), The "Social Logic” of Demobilization: Political Discussant Influence on Turnout and Abstention at the 2009 German General Election, The 6th ECPR General Conference, University of Iceland, Reykjavik/IS, August 25-27.

3. Perea, E. A., (2002), Individual characteristics, institutional incentives and electoral abstention in Western Europe, European Journal of Political Research, Vol. 41, Issue 5.

4. Šiber, I., (2004), Interest in Elections and Electoral Participation, Politička misao, Vol. XLI, No. 5.

5. Troumpounis, O., (2010), Institutions, Society or Protest? Explaining Abstention, Blank and Null Voting, Universitat Autonoma de Barcelona, http://idea.uab.es/orestis/research/Orestis_Troumpounis_ EM.pdf

6. Virós, R., (1994), A Qualitative Approach to Electoral Abstention, Universitat Pompeu Fabra, Working Paper no. 98, Barcelona, http://ddd. uab.cat/pub/worpap/1994/hdl_2072_1369/ICPS98.pdf

7. Barometrul de Opinie Publică octombrie 2007

8. Declinul participării la vot în România. Doar jumătate din participanţii la vot din 1990 mai sunt astăzi interesaţi să voteze, Institutul pentru Politici Publice Bucureşti, www.ipp.ro/protfiles.php?IDfile=56

9. Legea Votului uninominal, capitolul X, articolul 45, alin. 13: „Sunt voturi albe buletinele care nu au aplicată stampila «VOTAT». Aceste buletine nu intra în calculul voturilor valabil exprimate.” 